\title{
The Appealability of Orders Denying Motions for Disqualification of Counsel in the Federal Courts
}

The professional conduct of attorneys is challenged today perhaps more than ever before. Such challenges undoubtedly serve to educate practitioners in the profession's ethical canons and produce closer adherence to ethical principles. But the increase in challenges has a darker side as well. The motion to disqualify counsel is an especially effective litigation device. It can delay a trial, embarrass an opponent, and, if successful, deprive an adversary of his chosen and well-prepared counsel. ${ }^{1}$ Punctilious enforcement of the canons is often but disguised harassment of one's opponent. This problem has become serious because the modern corporate law firm, with its large and fluid membership and clientele, tends naturally to produce both real and apparent conflicts of interest. ${ }^{2}$ Apparent conflicts of interest can be seized upon by unscrupulous or overzealous counsel and used to bludgeon an opposing party and his counsel, whose actions may have been entirely innocent. ${ }^{3}$

The availability of appeal from the trial judge's ruling on the motion to disqualify offers further prospect for delay and harassment. Yet because of the potentially serious effects of an erroneous order disqualifying or refusing to disqualify counsel, there is much force to the argument that immediate appeal is necessary in order to settle the issue justly and efficiently, once and for all. At present, the majority of the circuits hold orders granting and denying such motions appealable by right. ${ }^{4}$ Recent cases indicate, however, that

1 Courts have also recognized that application of harsh disqualification tests might make it difficult for some parties to obtain competent counsel in highly specialized fields, Laskey Bros., Inc. v. Warner Bros. Pictures, 224 F.2d 824, 827 (2d Cir, 1955), and that attorneys might be closed out of their legal specialty. Consolidated Theatres v. Warner Bros. Circuit Management Corp., 216 F.2d 920, 926 (2d Cir. 1954). See Note, Disqualification of Attorneys for Representing Interests Adverse to Former Clients, 64 Y ALE L.J. 916, 928 (1955).

2 See Community Broadcasting of Boston, Inc. v. FCC, 546 F.2d 1022, 1027 (D.C. Cir. 1976); Silver Chrysler Motor, Inc. v. Chrysler Motors Corp., 496 F.2d 801, 803 (2d Cir. 1974).

${ }^{3}$ See, e.g., Pioche Mines Consol., Inc. v. Dolman, 333 F.2d 257, 259-60, 265 (9th Cir. 1964), cert. denied, 380 U.S. 956 (1965).

Orders granting disqualification motions have long been held appealable. See, e.g., New Mexico v. Aamodt, 537 F.2d 1102, 1106 (10th Cir. 1976); In re Gopman, 531 F.2d 262 (5th Cir. 1976); Brown v. Miller, 286 F.2d 994 (D.C. Cir. 1923). As for orders denying disqualification, eight circuits now hold them appealable. See Silver Chrysler Plymouth, Inc. v. Chrysler Motors Corp., 496 F.2d 800 (2d Cir. 1974); Greene v. Singer Co., 509 F.2d 750 (3d Cir. 1971), cert. denied, 409 U.S. 848 (1972); Mackeithan v. Peat, Marwick, Mitchell \& Co., 557 F.2d 395 (4th Cir. 1977); Tomlinson v. Florida Iron \& Metal Co., 291 F.2d 333 (5th Cir. 1961); Melamed v. ITT Continental Baking Co., 534 F.2d 82 (6th Cir. 1976); Schloetter v. Railoc of Ind., Inc., 546 F.2d 706, 709 (7th Cir. 1976); Fred Weber, Inc. v. Shell Oil Co., 566 


\section{the appealability of orders denying motions to disqualify is again controverted, ${ }^{5}$ largely because of the volume of appeals ${ }^{6}$ and their potential for abuse.}

F.2d 602 (8th Cir. 1977); Fullmer v. Harper, 517 F.2d 20, 21 (10th Cir. 1975). Two circuits have held such orders unappealable. See Community Broadcasting of Boston, Inc. v. FCC, 546 F.2d 1022 (D.C. Cir. 1976); Cord v. Smith, 338 F.2d 516, 521-22 (9th Cir. 1964), clarified, 370 F.2d 418 (9th Cir. 1966). Community Broadcasting only rejected appeals from orders denying motions to disqualify counsel on ethical, as opposed to statutory, grounds, avoiding overturning circuit precedent. See Yablonski v. United Mine Workers, 454 F.2d 1036, 1038 n.9 (D.C. Cir. 1971), cert. denied, 406 U.S. 906 (1972). The court reiterated the distinction in In re Investigation before April 1975 Grand Jury, 531 F.2d 600, 605 n.8 (D.C. Cir. 1976). Its rationale was that "the situation differs materially [from disqualification solely on ethical grounds] where the disqualification was predicated 'additionally upon significant impingement on a specific legislative policy'." Impingements on statutory schemes are, however, not so different from violations of ethical canons in their practical effects as to require different appellate treatment.

By comparison, state courts use varying procedures to obtain direct appellate review of orders denying motions for disqualification of counsel. E.g., Meehan v. Hopps, 45 Cal. 2d 213, 288 P.2d 267 (1955) (denial deemed denial of injunction and thus appealable under state law); Brasseaux v. Girouard, 214 So. 2d 401 (La. Ct. of App.) (appeal taken on certiorari), writ refused, 253 La. 59, 216 So. 2d 307 (1968); Kurbitz v. Kurbitz, 77 Wash. 2d 943, 468 P.2d 673 (1970) (appeal taken on certiorari). See 38 Tex. L. REv. 792 (1960), comparing the ruling in Fleischer v. Phillips, 264 F.2d 515 (2d Cir.), cert. denied, 359 U.S. 1002 (1959), with Texas state procedure.

s In addition to being rejected outright by the District of Columbia Circuit, Community Broadcasting of Boston, Inc. v. FCC, 546 F.2d 1022 (D.C. Cir. 1976), the rule permitting appeal of right from disqualification denials has been criticized by the First Circuit, Grinnell Corp. v. Hackett, 519 F.2d 595, 598 n.4 (1st Cir.), cert. denied, 423 U.S. 1033 (1975); and the Third Circuit, where the rule allowing appeals supposedly was settled, has called the issue a "close one." Hackett v. General Host Corp., 455 F.2d 618 (3d Cir.), cert. denied, 407 U.S. 925 (1972). Courts that follow Silver Chrysler have refused to apply the Silver Chrysler rule in a stockholder's derivative suit, Glenn v. Arkansas Best Corp., 525 F.2d 1216 (5th Cir. 1975), and in a class action suit. Handwerger v. Ginsberg, 519 F.2d 1339 (2d Cir. 1975).

More significantly, the Second Circuit has emphasized that it will reverse disqualification denials only in cases involving injury to the moving party and suggested that it might limit appealability to such as well. See, e.g., W.T. Grant Co. v. Haines, 531 F.2d 671, 676-77 (2d Cir. 1976); Lefrak v. Arabian Am. Oil Co., 527 F.2d 1136, 1139 (2d Cir. 1975). There is even sentiment among some Second Circuit judges that the time may be near for en banc reconsideration of the Silver Chrysler decision. See Allegaert v. Perot, 565 F.2d 246, 251 (2d Cir. 1977); Van Graafeiland, Lawyer's Conflict of Interest-A Judge's View (pt. II), 178 N.Y.L.J. No. 13, July 30 , 1977, at 1.

- Recent Second Circuit cases include Fund of Funds, Ltd. v. Arthur Anderson \& Co., No. 77-7387 (2d Cir., Nov. 7, 1977); Allegaert v. Perot, 565 F.2d 246 (2d Cir. 1977); SEC v. Sloan, 535 F.2d 679 (2d Cir. 1976); J.P. Foley \& Co. v. Vanderbilt, 523 F.2d 1357 (2d Cir. 1975); Hull v. Celanese Corp., 513 F.2d 568 (2d Cir. 1975); Ceramco, Inc. v. Lee Pharmaceuticals, 510 F.2d 268 (2d Cir. 1975); General Motors Corp. v. City of New York, 501 F.2d 639 (2d Cir. 1975).

Recent Third Circuit cases include Ackerly v. Red Barn Sys., Inc., 551 F.2d 539 (3d Cir. 1977); Kramer v. Scientific Control Corp., 534 F.2d 1085 (3d Cir. 1976); Kroungold v. Triester, 521 F.2d 763 (3d Cir. 1975); American Roller Co. v. Budinger, 513 F.2d 982 (3d Cir. 1975).

Recent Fifth Circuit cases include Wilson P. Abraham Constr. Corp. v. Armco Steel Corp., 559 F.2d 250 (5th Cir. 1977); In re Yarn Processing Patent Validity Litigation, 530 F.2d 83 (5th Cir. 1976).

All other circuits except the First have faced such appeals, though in lesser number. 
This comment examines the appealability of orders denying disqualification in the federal courts. The cornerstone of federal appellate jurisdiction is the final judgment rule, ${ }^{7}$ which, as codified in section 1291 of the Judicial Code, allows appeal "from all final decisions of the district courts of the United States, . . . except where a direct review may be had in the Supreme Court." Conditioning appealability on a final judgment serves several purposes. Consolidating review of all the issues of a case in a single, comprehensive proceeding avoids piecemeal review and the attendant "mischief of economic waste and of delayed justice,", and is thought to promote better-informed decisions. ${ }^{10}$ The rule also reduces the number of issues to be considered on appeal because many potential points of appeal are corrected in the course of trial, prove nonprejudicial, or are mooted by the outcome. The final judgment rule can nevertheless lead to unjust results or inefficiencies in certain circumstances. Statutory and judicial exceptions have therefore been created to mitigate its effects. Because orders denying motions to disqualify counsel are obviously not final decisions on the merits of the lawsuit, they must meet the requirements of one of these exceptions in order to be appealable. The exceptions are generally of two types: those allowing appeal of right, and those allowing discretionary appeal.

\section{Direct Appeal of Right: The Cohen Collateral Order DOCTRINE}

The only arguably applicable exception ${ }^{11}$ to the final judgment

7 See 9 Moore's Federal Practice I 110.06, at 105-07 (2d ed. 1975) [hereinafter cited as MOore's]. The importance of finality has recently been reemphasized in United States v. Nixon, 418 U.S. 683,690 (1974).

s 28 U.S.C. \& 1291 (1970).

- Radio Station WOW, Inc. v. Johnson, 326 U.S. 120, 124 (1945).

${ }^{10}$ See, e.g., Baltimore Contractors, Inc. v. Bodinger, 348 U.S. 176, 180-81 (1955); Heike v. United States, 217 U.S. 423, 428-29 (1910); McLish v. Roff, 141 U.S. 661, $665-66$ (1891); 9 MOORE's, supra note 7, \110.07 at 107-11. For historical analysis of the final judgment rule, see Crick, The Final Judgment as a Basis for Appeal, 41 Yale L.J. 539 (1932).

"The language of Gillespie v. United States Steel Corp., 379 U.S. 148, 153, 154 (1964) (Black, J.), might seem to expand appellate jurisdiction to any question "fundamental to the further conduct of the case." An exception phrased so broadly would eliminate the final judgment rule altogether. Few significant court orders cannot be characterized as "fundamental to the further conduct of the case," including orders concerning discovery, admission of evidence, and challenges to the jury.

The Gillespie opinion cannot support appeals by right of orders denying disqualification, however, because the reasoning of the case is fairly confused. It must be either rejected or reinterpreted. The Court upheld the assumption of jurisdiction by the court of appeals, noting the difficulty of the question and saying, "We cannot say that the court of appeals chose wrongly under the circumstances." Id. at 153 . The Court also noted that the petitioner's 
rule allowing appeal of right from orders denying disqualification is the collateral order exception announced by the Supreme Court in Cohen v. Beneficial Industrial Loan Corp. ${ }^{12}$ In Silver Chrysler Plymouth, Inc. v. Chrysler Motors Corp. ${ }^{13}$ and Tomlinson v. Florida Iron \& Metal Co. ${ }^{14}$ the Second and Fifth Circuits, respectively, relied squarely on Cohen in holding that disqualification denials are immediately appealable under section 1291. The opinions in those cases, however, are short on analysis; they do not specify the characteristics of such orders that were thought to bring them within the Cohen exception. In Silver Chrysler the court simply asserted that "all three prerequisites of Cohen are met."15 A more careful analysis reveals that denials of disqualification motions do not meet the Cohen criteria, and that strong policy reasons disfavor allowing appeals of right from disqualification denials.

claims "are not formally severable so as to make the court's order unquestionably appealable as to them." Id. This would imply that the court of appeals had discretion whether to hear the appeal. This approach is dubious; appeals under $\$ 1291$ are appeals of right, not subject to the discretion of the courts of appeals. The court of appeals' determination is subject to review by the Supreme Court.

Dubious as this first proposition may be, the Court compounded the confusion by saying:

It is true that if the District Judge had certified the case to the Court of Appeals under 28 U.S.C. $\S 1292$ (b) (1958 ed.), the appeal unquestionably would have been proper; in the light of the circumstances we believe that the Court of Appeals properly implemented the same policy Congress sought to promote in $\S 1292$ (b) by treating this obviously marginal case as final and appealable under 28 U.S.C. $\$ 1291$ (1958 ed.).

Id. at 154. This dictum seems to imply that if an order certifiable for interlocutory appeal under $\S 1292$ (b) by the district judge is not so certified, the court of appeals may at its discretion hear the appeal anyway. Such an interpretation of $\S 1292(b)$ (called "clearly incorrect" in Note, Interlocutory Appeals in the Federal Courts under 28 U.S.C. $\$ 1292(b)$, 88 HaRv. L. REv. 607, 614 (1975)) would abrogate the requirement of certification, making appealable under $\S 1292$ (b) whatever the appellate court chooses to hear, a position clearly contrary to the statute.

Moreover, this interpretation flatly contradicts the Court's previous conclusion that the order was appealable under $\$ 1291$. If, as stated by the Court, the order involved in Gillespie would "unquestionably" have been a proper subject for $\S 1292$ (b) appeal, then it could not also have been a final order appealable under $\S 1291$, because $\$ 1292(\mathrm{~b})$ permits appeal only of orders "not otherwise appealable under this section."

Thus, the Gillespie opinion, which admits to the impossibility of devising a rule to judge finality, cannot serve as a valid basis for enlarging appeals beyond the strictures of Cohen and its counterparts. See 379 U.S. at 167-70 (Harlan, J., dissenting).

Some commentators, e.g., 9 Moore's, supra note 7, ๆ 110.12, at 150-52, have reinterpreted Gillespie to create a separate exception to the finality principle, granting the appellate courts the power to hear the merits of an appeal after time and resources have already been expended on hearing the jurisdictional issue. This discretion would give no right of appeal to litigants, and could be exercised only where appealability was a close question and the issue "fundamental" to the case below. So interpreted, Gillespie does not support appeals by right of disqualification denials.

12337 U.S. 541 (1949).

13 496 F.2d 800 (2d Cir. 1974).

it 291 F.2d 333 (5th Cir. 1961).

15 496 F.2d at 805 . 


\section{A. The Cohen Requisites}

Cohen v. Beneficial Industrial Loan Corp.,$^{16}$ a diversity suit, involved an appeal from an order denying defendant's motion to require the plaintiff to post bond for payment of expenses in a stockholder derivative suit, as required by state statute. The court of appeals accepted the appeal and reversed, and the Supreme Court granted certiorari. Applying a "practical rather than a technical construction"17 to section 1291's requirement of a final decision, the Court held the order appealable on the ground that the decision fell within a "small class which finally determine claims of right separable from, and collateral to, rights asserted in the action, too important to be denied review and too independent of the cause itself to require that appellate consideration be deferred until the whole case is adjudicated."18

Four requisites of section 1291 appealability can be distilled from the above passage and other language in the opinion. The order must be (1) collateral-the issues bearing on the order must be essentially unrelated to the issues of the main dispute; $;^{19}(2)$ conclusive-the order must be final, neither tentative nor incomplete; ${ }^{20}(3)$

is 337 U.S. 541 (1949).

"Id. at 546. The three cases cited in Cohen to illustrate the "practical" construction of the finality statute provide little guidance as to the Court's meaning. Bank of Columbia v. Sweeny, 26 U.S. (1 Pet.) 567 (1828), and Cobbledick v. United States, 309 U.S. 323 (1940), both hewed strictly to the final judgment rule. United States v. River Rouge Co., 269 U.S. 411 (1925) is analogous to the exception of rule 54(b) of the Federal Rules of Civil Procedure, and represents the policies behind that rule rather than the Cohen doctrine.

A true pragmatic approach to finality might be to treat those orders as final which effectively dispose of litigation, even though not terminating it in a technical sense. This approach would not support the collateral order exception in most circumstances, including those in Cohen. It would, however, provide strong support for such decisions as Forgay v. Conrad, 47 U.S. (6 How.) 200 (1848); Swift \& Co. Packers v. Compania Colombiana del Caribe, S.A., 339 U.S. 684 (1950); Roberts v. United States Dist. Court, 339 U.S. 844 (1950) (per curiam); Eisen v. Carlisle \& Jacquelin, 370 F.2d 119 (2d Cir. 1966), cert. denied, 386 U.S. 1035 (1967) (death knell doctrine); United States v. Wood, 295 F.2d 772 (5th Cir. 1961), cert. denied, 369 U.S. 850 (1962). See Redish, The Pragmatic Approach to Appealability in the Federal Courts, 75 CoLum. L. Rev. 89 (1975). This pragmatic approach would not support appeals of orders denying motions for disqualification because such orders do not terminate the litigation, either practically or technically.

18337 U.S. at 546.

1 But this order of the District Court did not make any step toward final disposition of the merits of the case and will not be merged in final judgment. . . . We conclude that the matters embraced in the decision appealed from are not of such an interlocutory nature as to affect, or to be affected by, decision of the merits of this case.

$I d$. The issue was further described as "not an ingredient of the cause of action." Id. at 546-47.

${ }^{20}$ The effect of [28 U.S.C. $\left.\$ 1291\right]$ is to disallow appeal from any decision which is tentative, informal or incomplete. Appeal gives the upper court a power of review, not one of intervention. So long as the matter remains open, unfinished or inconclusive, 
impracticable of appeal from final judgment-the asserted right "will have been lost, probably irreparably" if review is delayed;" and (4) of public importance-the order should involve "a serious and unsettled question," and not simply the exercise of trial court discretion. ${ }^{22}$ It is unclear, however, whether all of these requirements have survived the Supreme Court decisions that have been handed down since Cohen. The Court failed in many subsequent cases to make explicit the factors it considers in deciding whether interlocutory orders are appealable under section $1291 .^{23}$ Some decisions mention none of the four Cohen requisites; ${ }^{24}$ others mention only two or three. ${ }^{25}$ In its most recent collateral order decision the Court insisted on the first three requisites enumerated above, ${ }^{26}$ which represent the bare minimum that must be retained unless the Cohen doctrine is to undermine completely the final decision rule. Some courts have continued to require "public importance," 27 even

there may be no intrusion by appeal. But the District Court's action upon this application was concluded and closed and its decision final in that sense before the appeal was taken.

Id. at 546.

${ }^{21}$ "When [the time of final disposition of the case] comes, it will be too late effectively to review the present order, and the rights conferred by the statute, if it is applicable, will have been lost, probably irreparably." Id.

22 The appealed claim was described as "too important to be denied review." Id. The Cohen court defined "importance" in terms of whether the appeal presents a "serious and unsettled question," as opposed to involving "the exercise of discretion":

$[W]$ e do not mean that every order fixing security is subject to appeal. Here it is the right to security that presents a serious and unsettled question. If the right were admitted or clear and the order involved only an exercise of discretion as to the amount of security . . . appealability would present a different question.

Id. at 547. The distinction captures the essence of the issue. If, in a class of orders, factual variations will be many and significant and the legal determination will depend upon the weighing of conflicting considerations, no individual case will involve "serious and unsettled" questions, at least once the proper standards to be applied have been established.

This "importance" is referred to in this comment as "public importance" in order to distinguish it from the importance of the question to the parties themselves. The Cohen decision plainly had a "public importance" beyond the individual action.

${ }^{23}$ Perhaps this may be attributed to the difficulty of harmonizing the conflicting tensions between justice and judicial economy. See Dickinson v. Petroleum Conversion Corp., 338 U.S. $507,511(1950)$.

24 Stack v. Boyle, 342 U.S. 1 (1951) (order denying reduction of bail); Roberts v. United States Dist. Court, 339 U.S. 844 (1950) (per curiam) (order denying motion to proceed in forma pauperis).

${ }^{25}$ See Abney v. United States, 431 U.S. 651 (1977) (order rejecting criminal defense of double jeopardy); Eisen v. Carlisle \& Jacquelin, 417 U.S. 156 (1974) (order requiring class action defendants to bear ninety percent of notice expenses held appealable); Swift \& Co. Packers v. Compania Columbiana del Caribe, S.A., 339 U.S. 684 (1950) (order dissolving foreign attachment of a vessel held appealable).

2t Abney v. United States, 431 U.S. 651 (1977).

${ }^{27}$ See, e.g., Phillips v. Tobin, 548 F.2d 408, 410 (2d Cir. 1976); Grinnell Corp. v. Hackett, 519 F.2d 595, 597-98 (1st Cir.), cert. denied, 423 U.S. 1033 (1975); Ronson Corp. v. Liquifin 
though the Court has not emphasized it in recent cases. ${ }^{28}$ For present purposes, it is not necessary to determine whether "public importance" remains a necessary element (although, as argued below, there are sound policy reasons for retaining it) because orders denying attorney disqualification do not satisfy the Cohen test of impracticability of appeal from final judgment, let alone the test of public importance. ${ }^{29}$

\section{Impracticability of Appeal from Final Judgment.}

a. Harm to the movant. It is plausible to argue, as did the court in Silver Chrysler ${ }^{30}$ that the harm to the movant from an improper denial of his motion to disqualify cannot be rectified completely by an appeal from final judgment. In Cohen and its Supreme Court progeny, however, the possibility of any relief, not merely the adequacy or completeness of the relief, was at stake. The right of a litigant to be protected from the unethical conduct of an opponent's counsel can be vindicated by appeal from final judgment. Unlike cases involving the right to compel the posting of pretrial security, ${ }^{31}$ the right to reduction of bail, ${ }^{32}$ or double jeopardy, ${ }^{33}$ disqualification

Aktiengesellschaft, 508 F.2d 399, 401-02 (2d Cir. 1974); General Motors Corp. v. City of New York, 501 F.2d 639, 647 (2d Cir. 1974); IBM Corp. v. United States, 480 F.2d 293, 298 (2d Cir. 1973); Donlon Indus. v. Forte, 402 F.2d 935, 937 (2d Cir. 1968); United States v. Fried, 386 F.2d 691, 694 (2d Cir. 1967); Bancroft Navigation Co. v. Chadade S.S. Co., 349 F.2d 527, 529-30 (2d Cir. 1965); 9 Moore's, supra note 7, ๆ 110.10 at 133; C. WRIGHT, HaNdBOOK of THE LAW of THE FEDERAL CourTs $\S 101$, at $509 \mathrm{n} .36$ (3d ed. 1976). See also West v. Zurhorst, 425 F.2d 919, 921 (2d Cir. 1970).

${ }^{28}$ Perhaps the most conspicuous example is the Supreme Court's recent opinion in Abney v. United States, 431 U.S. 651 (1977), where Chief Justice Burger's opinion for the majority did not even mention "public importance."

In one sense every case decided by the Court under its certiorari jurisdiction has the requisite public importance. It is hardly likely that the Court would find the issue of appealability in a case important enough to grant certiorari, and then hold the issue of insufficient public importance to warrant appeal. See Stack v. Boyle, 342 U.S. 1, 12-13 (1951) (Jackson, J., concurring). This might account for the Court's lack of emphasis on the point, in contrast to the circuit courts who must make a separate determination of public importance in judging appealability.

${ }^{29}$ However, both the "collateral" and the "conclusive" elements are present. Orders regarding disqualification are collateral to the main cause in the sense that factual issues bearing on disqualification are usually unrelated to the basic issues of the litigation. Although the requirement of conclusiveness is less clearly met since the trial judge, upon further evidence, might grant the motion later, see Fleischer v. Phillips, 264 F.2d 515 (2d Cir.), cert. denied, 359 U.S. 1002 (1959), as a practical matter orders denying disqualification are not "tentative, informal, or incomplete," but rather settle the issue, permanently barring appeal or reconsideration. Rarely would such new evidence appear after the order that the judge would change his mind.

${ }^{30} 496$ F.2d 800, 805 (2d Cir. 1974). See also Greene v. Singer Co., 509 F.2d 750 (3d Cir. 1971), cert. denied, 409 U.S. 848 (1972).

si Cohen v. Beneficial Indus. Loan Corp., 337 U.S. 541 (1949).

32 Stack v. Boyle, 342 U.S. 1 (1951).

${ }^{3}$ Abney v. United States, 431 U.S. 651 (1977). The other Supreme Court cases similarly 
denial cases involve the danger of prejudice to a party's conduct of his lawsuit, especially where the ground for disqualification is the possibility that opposing counsel will disclose the party's confidences. Prejudice to the litigation, however, can be corrected by a new trial, coupled if necessary with replication of pretrial proceedings. This remedy may be less than ideal from the movant's point of view, both because damage from an attorney's improper disclosure of confidences perhaps might never be fully corrected, ${ }^{34}$ and because retrial is costly and inconvenient. The disclosure problem, however, is no more curable by an immediate appeal; the challenged attorney will generally have had ample opportunity to disclose all that he knows before he is disqualified upon appeal. The problem of expense and inconvenience of waiting for final judgment ${ }^{35}$ has never been considered a sufficient ground for deviating from the final judgment rule. As the Supreme Court commented in Roche $v$. Evaporated Milk Association, ${ }^{36}$ a mandamus case, "trial may be of several months duration and may be correspondingly costly and inconvenient. But that inconvenience is one which we must take it Congress contemplated in providing that only final judgments should be reviewable." 37

Erroneous orders denying disqualification are similar to erroneous discovery orders. Erroneous discovery orders may expose materials that the party had a right to keep confidential or may deny a party access to information needed for conducting a fair trial.

involve situations in which there was no possibility of review. See, e.g., Eisen v. Carlisle \& Jacquelin, 417 U.S. 156 (1974) (order requiring a class action defendant to pay $90 \%$ of notice costs, where the suit was likely to be dropped if representative plaintiffs had to pay the costs); Swift \& Co. Packers v. Compania Colombiana del Caribe, S.A., 339 U.S. 684 (1950) (order releasing a vessel from foreign attachment and thereby destroying the in rem jurisdiction of the court). As the Court said in another context, "Only in the limited class of cases where denial of immediate review would render impossible any review whatsoever of an individual's claims have we allowed exceptions to this principle." United States v. Ryan, 402 U.S. 530, 533 (1971) (emphasis added).

${ }^{34}$ Harmer Drive-In Theatre v. Warner Bros. Pictures, 239 F.2d 555, 558 n.3 (2d Cir. 1956) (Clark, C.J., dissenting).

is The rhetorical construction of the Silver Chrysler opinion makes it apparent that the "grave consequences to the losing party" from denial of its motion for disqualification consisted primarily of uncertainty, paperwork, and legal time:

By holding such an order directly appealable, we eliminate the uncertainties (and the paperwork) attendant to resorting to $\S 1292(\mathrm{~b})$ and/or $\S 1651$. Since the ultimate objective is to bring before an appellate court an important question which, if unresolved, might well taint a trial, why should not this question be presented before judicial and attorney time may have been needlessly expended?

496 F.2d at 806 . Such inconveniences do not satisfy the impracticability of appeal from final judgment standard.

36319 U.S. 21 (1943).

37 Id. at 30. 
They cannot be remedied after final judgment except by a new trial and perhaps new pretrial proceedings as well. Nevertheless, courts have generally held discovery orders unappealable ${ }^{38}$ reasoning that "since review is ultimately available upon appeal from the final judgment in the action, unnecessary intermediate appeals only serve to delay trial and to provide an opportunity for harassment and abuse ....",

b. Harm to the judicial system. It might be said that a kind of harm that cannot be remedied on appeal is the injury to the judicial system caused by the loss of public confidence in the courts when a lawyer who should be disqualified is allowed to participate in the trial. One might argue that direct appeal of orders disqualifying counsel is necessary because the public appearance of impropriety cannot be remedied upon appeal from final judgment. This argument is unpersuasive, for at least three reasons.

First, it seems doubtful that public confidence in the legal system would be much affected by allowing disqualification denials to stand until corrected on appeal from final judgment, especially if alternative modes of review are available for more important or egregious cases. ${ }^{40}$ Although there is some truth in the oft-repeated idea that "[ $t]$ he stature of the profession and the courts, and the esteem in which they are held, are dependent upon the complete absence of even a semblance of improper conduct," ${ }_{11}$ the argument

${ }^{38}$ See Baker v. United States Steel Corp., 492 F.2d 1074 (2d Cir. 1974), and cases cited therein; 9 MooRE's, supra note 7, I 110.13[2], at 153-59. See also Alexander v. United States, 201 U.S. 117 (1906); Borden Co. v. Sylk, 410 F.2d 843 (3d Cir. 1969); American Express Warehousing v. Transamerican Ins. Co., 380 F.2d 277, 281-82 (2d Cir. 1967). But see Covey Oil Co. v. Continental Oil Co., 340 F.2d 993 (10th Cir.), cert. denied, 380 U.S. 964 (1965) (appeal granted because appellant was not a party and therefore could not challenge the final judgment).

${ }^{39}$ Baker v. United States Steel Corp., 492 F.2d 1074, 1077 (2d Cir. 1974).

Orders granting and orders denying motions for disqualification differ sharply with respect to the possibility of obtaining relief upon appeal from final judgment. Unlike disqualification denials, orders granting disqualification are subject to appellate review after final judgment. If, after the disqualification, the party wins the case, the disqualification becomes moot despite the cost that disqualification imposed on the party. If the party whose attorney is disqualified loses the case, then the error would be viewed as non-prejudicial, except possibly in the most extreme circumstances. This is because, to prove prejudice, it would be necessary to establish that replacement counsel had been so incompetent and unprepared relative to former counsel as to have affected the case. Such a situation is improbable. As the court commented in E.F. Hutton \& Co. v. Brown, 305 F. Supp. 371 (S.D. Tex. 1969), "A delayed appeal of this order of disqualification would be no appeal, for if plaintiff is required to obtain new counsel and try this suit before appealing the order of disqualification, the order will have become moot." Id. at 402 .

to See generally Section II infra.

" Emle Indus., Inc. v. Patentex, Inc., 478 F.2d 562, 575 (2d Cir. 1973). 
almost surely exaggerates the public's awareness of disqualification disputes.

Second, it is difficult to see how the appearance of impropriety can justify immediate appeal when, despite dicta to the contrary, ${ }^{12}$ merely apparent impropriety is often insufficient to warrant disqualification. ${ }^{43}$ Although many courts speak in disqualification cases of avoiding the "appearance of impropriety," this should not be taken to mean that apparent impropriety, in the absence of actual misconduct, is an adequate ground for disqualification. The "appearance of impropriety" language is taken from Canon 9 of the Code of Professional Responsibility. 44 The Canons and explanatory Ethical Considerations, however, are the aspirational objectives of the profession, stated in "general terms." 45 The Disciplinary Rules, which are "mandatory in character" and "state the minimum level of conduct below which no lawyer can fall without being subject to disciplinary action," 46 are more specific and do not require a lawyer to turn down employment simply because his accepting it might create some ill-defined "appearance of impropriety." 47 The most

12 See, e.g., Hull v. Celanese Corp., 513 F.2d 568, 571-72 (2d Cir. 1975); Emle Indus., Inc. v. Patentex, Inc., 478 F.2d 562, 571 (2d Cir. 1973); Marketti v. Fitzsimmons, 373 F. Supp. 637,639 (W.D. Wis. 1974). In each case there was a substantial risk of disclosure of confidential information.

${ }_{13}$ See, e.g., Fred Weber, Inc. v. Shell Oil Co., 566 F.2d 602, 616 (8th Cir. 1977); Woods v. Covington County Bank, 537 F.2d 804, 813 (5th Cir. 1976) ("there must be at least a reasonable possibility that some specifically identifiable impropriety did in fact occur"); Redd v. Shell Oil Co., 518 F.2d 311 (10th Cir. 1975); Ceramo, Inc. v. Lee Pharmaceuticals, 510 F.2d 268 (2d Cir. 1975); Note, The Second Circuit and Attorney Disqualification-Silver Chrysler Steers in a New Direction, 44 Fordham L. Rev. 130 (1975). See also Note, Disqualification of Attorneys for Representing Interests Adverse to Former Clients, 64 YALE L.J. 917 (1955).

" ABA Code of Professional Responsibility Canon 9 (1975): "A Lawyer Should Avoid Even the Appearance of Professional Impropriety."

45 Id. at 1 (Preamble and Preliminary Statement).

4 Id. The Code does not prescribe sanctions for violation of the disciplinary rules, but such sanctions include disbarment, suspension from practice, and civil liability. Disqualification from a particular suit is punitive, and thus has the effect of deterring violation. The central purpose of disqualification, however, is not to punish the errant attorney, but to protect the other party. W.T. Grant Co. v. Haines, 531 F.2d 671, 677 (2d Cir. 1976). It may be argued, then, that the relevance of the Code to disqualification proceedings is to serve as a standard for judging the reasonable expectations and rights of parties, rather than as rules, which, if broken, merit punishment.

"See Note, The Second Circuit and Attorney Disqualification-Silver Chrysier Steers in a New Direction, 44 Fordham L. REv. 130, 141-45 (1975). Only one reported case has been found in which a non-government attorney was disqualified in the absence of actual impropriety. W.E. Bassett Co. v. H.C. Cook Co., 201 F. Supp. 821 (D. Conn. 1961), aff'd per curiam, 302 F.2d 268 (2d Cir. 1962). The more typical situation occurs where an actual impropriety has been committed under one of the canons, and the court discusses the "appearance of impropriety" as well. E.g., General Motors Corp. v. City of New York, 501 F.2d 639 (2d Cir. 1974) (Canon 9); Emle Indus., Inc. v. Patentex, Inc., 478 F.2d 562 (2d Cir. 1973) (Canon 4). This might be interpreted as an attempt to soften the criticism of the attorney. 
common predicate for disqualification motions is not Canon 9 , but Canon 4, which states that "A Lawyer Should Preserve the Confidences and Secrets of a Client." 18 Under this canon, courts apply a "substantial relationship" test. If an attorney's present case bears a substantial relationship to an earlier case in which he represented an opposing party, the court will infer the passing of confidential information $^{49}$ and disqualify the challenged counsel. That the "substantial relationship" standard demands a close examination of the attorney's behavior and is not satisfied by the mere "appearance of impropriety" is attested by the Silver Chrysler case itself. Defendant Chrysler Motors argued that a former junior associate of its counsel should be disqualified from representing the plaintiff on grounds of possible appearance of impropriety. The district court rejected this standard and ruled that movant must show that the attorney undertook "[a]ctual activities on specific cases" from which it can reasonably be inferred that he gained information of value to his present client. ${ }^{50}$ Indeed, the court noted, public confidence in the legal system might be damaged if vague charges of impropriety were permitted to "form the sole basis for an unjust disqualification." 51

Third, Cohen and its progeny do not suggest that by impracticability of remedy the Court meant the difficulty of redressing the harm suffered by anyone other than a party involved in the lawsuit. For example, in Baker v. United States Steel Corp. ${ }^{52}$ the Second Circuit expressed concern that if the trial judge's ruling "ultimately should turn out to have been erroneous, considerable harm could result not only to appellants but also to the public interest in maintaining the confidentiality of grand jury proceedings,"53 but nevertheless held the order, which related to discovery, unappealable. Because "review is ultimately available upon appeal from final judgment," the court reluctantly, but correctly, held itself "powerless to act at this stage."

48 ABA Code of Professional Responsibility Canon 4 (1975).

9 Schloetter v. Railoc of Ind., Inc., 546 F.2d 706, 710 (7th Cir. 1976); Redd v. Shell Oil Co., 518 F.2d 311, 315 (10th Cir. 1975); American Roller Co. v. Budinger, 513 F.2d 982, 98485 (3d Cir. 1975); Marketti v. Fitzsimmons, 373 F. Supp. 637, 639 (W.D. Wis. 1974); United States v. Standard Oil Co., 136 F. Supp. 345, 354 (S.D.N.Y. 1955); T.C. Theatre Corp. v. Warner Bros. Pictures, Inc., 113 F. Supp. 265, 268 (S.D.N.Y. 1953).

so Silver Chrysler Plymouth, Inc. v. Chrysler Motors Corp., 370 F. Supp. 581, 589 (E.D.N.Y. 1973), appeal granted, 496 F.2d 800 (2d Cir. 1974), aff'd, 518 F.2d 751 (2d Cir. 1975).

s1 Id.

32492 F.2d 1074 (2d Cir. 1974).

ss Id. at 1078.

st Id. at 1079. 
2. Public Importance. Although the Supreme Court has not placed much emphasis on the public importance branch of the Cohen test in recent cases, strong reasons support its retention. The Cohen doctrine has engendered an uncomfortably large family of appealable orders ${ }^{55}$ at a time when the policy justification for appealability by right has become less pressing..$^{56}$ Alternative modes of review have developed since Cohen was decided-principally, interlocutory appeal under section 1292(b) and liberalized use of the writ of mandamus ${ }^{57}$ - which are less disruptive to the litigation, yet effectively mitigate the harshness of the final decision rule. Insistence upon the public importance requisite would keep Cohen appeals within reasonable bounds. This is because the public importance requirement serves the function of distinguishing cases where "a decision [on appeal] will settle a point once and for all" from cases where a decision "will open the way for a flood of appeals concerning the propriety of a district court's ruling on the facts of a particular suit." 58 As the Second Circuit explained in Donlon Industries, Inc. v. Forte ${ }^{59}$ a decision holding unappealable an order refusing to require the plaintiff in a securities case to provide an undertaking for defendant's costs:

Whether a court has power to require an undertaking is an issue of law, and an appellate decision will settle the matter not simply for the case in hand but for many others-as was notably true with the important issue in Cohen. In contrast, where the question is the propriety of an exercise of discretion in denying security, the factual variations are so numerous that a judgment on appeal can do little to establish meaningful standards. Furthermore, since review would be limited to "abuse" of discretion, the likelihood of reversal is too negligible to justify the delay and expense incident to an appeal and the consequent burden on hardpressed appellate courts. ${ }^{60}$

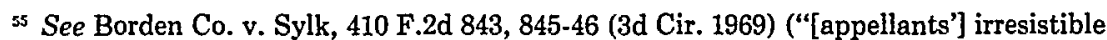
impulse to invoke the 'collateral order' doctrine whenever the question of appealability arises"); Bancroft Navigation Co. v. Chadade S.S. Co., 349 F.2d 527, 529-30 (2d Cir. 1965); 9 MooRE's, supra note $7, \uparrow 110.10$, at 133 .

s6 See 9 Moore's, supra note $7,110.10$, at $135-36$, suggesting that the Interlocutory Appeals Act of 1958, Pub. L. No. 85-919, 72 Stat. 1770 (codified at 28 U.S.C. \$ 1292 (1970)), the introduction of "supervisory mandamus," and the 1963 amendment to rule $54(\mathrm{~b})$ have made Cohen an unnecessary and undesirable exception.

${ }_{57}$ See generally Section II infra.

${ }^{5 x}$ Weight Watchers of Philadelphia, Inc. v. Weight Watchers Int'l, Inc., 455 F.2d 770, 773 (2d Cir. 1972).

sง 402 F.2d 935 (2d Cir. 1968).

${ }^{60}$ Id. at 937. See also Phillips v. Tobin, 548 F.2d 408, 410 (2d Cir. 1976); Grinnell Corp. v. Hackett, 519 F.2d 595, 597-98 (1st Cir.), cert. denied, 423 U.S. 1033 (1975). 
The public importance criterion also accords with a reasonable division of duties between trial and appellate courts. In making factual judgments, or in applying general standards to particular fact situations, the trial court's judgment should rarely be disturbed. Only where a legal issue of general applicability is concerned is the appellate court decidedly more competent. This division of duties, reflected in the "clearly erroneous" and "incorrect" standards for reversal, should also be reflected in the standards for direct appealability.

To determine whether disqualification denials generally involve matters of "public importance," it is therefore necessary to determine the extent to which trial judge rulings on motions to disqualify involve the exercise of discretion. The majority view, challenged only by the Fifth Circuit ${ }^{61}$ and unheeded dicta in the Third, ${ }^{62}$ is that district judges have wide discretion in granting or denying motions for disqualification. Such orders will be reversed only on a showing of "abuse of discretion," whatever the procedural context. ${ }^{83}$ The factual situations out of which disqualification motions arise tend to be individuated and complex. ${ }^{64}$ It may be necessary to distinguish

s1 Woods v. Covington County Bank, 537 F.2d 804, 810 (5th Cir. 1976). Woods reflected a switch in a single year from the majority view clearly espoused in In re Gopman, 531 F.2d 262, 266 (5th Cir. 1976).

${ }^{62}$ See American Roller Co. v. Budinger, 513 F.2d 982 (3d Cir. 1975):

We have serious reservations, however, whether our scope of review is limited to finding an abuse of discretion in disqualification cases such as this. It appears that in issue in these cases is the purely legal question of whether two allegedly adverse representations are so intertwined that it can be said that in the former representation the attorney "might have acquired" material "substantially related" to the subject matter of the second representation. Determination of that question leaves little leeway for the exercise of discretion.

Id. at 985 n.3. The Third Circuit continued to apply the "abuse of discretion" standard in disqualification appeals in Kroungold v. Triester, $521 \mathrm{~F} .2 \mathrm{~d} 763$ (3d Cir. 1975), while restating American Roller's reservations. Id. at 765 n.2. Kramer v. Scientific Control Corp., 534 F.2d 1085 (3d Cir. 1976), while not deciding the question of the appropriate standard of review, commented that "in many contexts disqualification motions present purely legal issues, subject to full appellate review." Id. at 1088. The Fifth Circuit was apparently persuaded, for it cited American Roller in Woods v. Covington County Bank, 537 F.2d 804, 810 (5th Cir. 1976).

s E.g., Fred Weber, Inc. v. Shell Oil Co., 566 F.2d 602 (8th Cir. 1977); Schloetter v. Railoc of Ind., Inc., 546 F.2d 706, 710 (7th Cir. 1976); Gas-A-Tron v. Union Oil Co., 534 F.2d 1322, 1324-25 (9th Cir.), cert. denied, 429 U.S. 861 (1976); In re Gopman, 531 F.2d 262, 266 (5th Cir. 1976); Hull v. Celanese Corp., 513 F.2d 568, 571 (2d Cir. 1975); Richardson v. Hamilton Int'l Corp., 469 F.2d 1382, 1385-86 (3d Cir. 1972), cert. denied, 411 U.S. 986 (1973); Waters v. Western Co. of N. Am., 436 F.2d 1072, 1073 (10th Cir. 1971).

os See, e.g., Fund of Funds, Ltd. v. Arthur Anderson \& Co., No. 77-7387 (2d Cir. Nov. 7, 1977) (facts presented and analyzed with "painstaking care"); Silver Chrysler Plymouth, Inc. v. Chrysler Motors Corp., 370 F. Supp. 581 (E.D.N.Y. 1973), aff'd, 518 F.2d 751 (2d Cir. 1975); Uniweld Products, Inc. v. Union Carbide Corp., 385 F.2d. 992, 995 (5th Cir. 1967), cert. denied, 390 U.S. 921 (1968) ("the issues before the trial court were essentially issues of fact"); 
between appearance of and actual impropriety, and to give each its proper weight. ${ }^{65}$ The balancing of the parties' interests may turn on very subtle aspects of the situation. ${ }^{66}$ Moreover, the records of disqualification cases are often inadequate to allow careful appellate review of trial judges' applications of ethical standards. ${ }^{87}$ In view of the district judge's greater familiarity with the intricacies of the case and the ramifications of the order, and because of the importance of preserving the trial judge's control over the proceedings in his court, ${ }^{68}$ his decision should be entitled to great deference.

Given that disqualification denials are discretionary in nature, and therefore will not typically present "serious and unsettled" questions, ${ }^{69}$ it is hard to identify any public importance element in most such orders. The only conceivable basis for finding the requisite public importance lies in the generalized public interest in promoting legal ethics. Recognizing that "it is difficult to understand how every order refusing to disqualify is important," the First Circuit in Grinnell Corp. v. Hackett ${ }^{70}$ speculated in similar vein that interlocutory appeal had been granted by the Second Circuit in Silver Chrysler because of "an overriding concern . . . for avoiding any interim appearance of impropriety." "Such suggestions are unpersuasive, however. That a general class of issues is of public importance does not imply that any particular case in that class has similar importance. Were it otherwise, every interlocutory order implicating in some way an important policy concern-in other words, virtually every interlocutory order-would be appealable by right, provided that the other Cohen requisites were met. The argument also overstates the public awareness of disqualification litigation. Moreover, the substantive standard of disqualification requires more than the mere appearance of impropriety. ${ }^{72}$ If public confidence can survive representations having an appearance of

United States v. Standard Oil Co., 136 F. Supp. 345 (S.D.N.Y. 1955) (conclusion reached after a thorough document-by-document analysis).

as Waters v. Western Co. of N. Am., 436 F.2d 1072, 1073 (10th Cir. 1971).

8s Woods v. Covington County Bank, 537 F.2d 804, 813 \& n.12 (5th Cir. 1976).

or See, e.g., Melamed v. ITT Continental Baking Co., 534 F.2d 82 (6th Cir. 1976); Waters v. Western Co. of N. Am., 436 F.2d 1072 (10th Cir. 1971).

s Ex parte Burr, 22 U.S. (9 Wheat.) 529, 530-31 (1824).

6 This distinction, between orders presenting "serious and unsettled" questions and those involving "the exercise of discretion," was the one made in Cohen v. Beneficial Indus. Loan Corp., 337 U.S. 541,547 (1949). See note 22 supra.

${ }^{70}$ Grinnell Corp. v. Hackett, 519 F.2d 595 (1st Cir.), cert. denied, 423 U.S. 1033 (1975).

"Id. at 597 n.4. The Grinnell court also speculated that the "importance" might be found in the Silver Chrysler court's overriding concern for judicial economy. Id. at 598 n.4. See note 73 infra.

${ }^{72}$ See text and notes at notes 42-51 supra. 
impropriety, surely it can survive the appearance of impropriety in the interim between the trial court's ruling and final judgment.

\section{B. Policy Reasons for Rejecting Appeal of Right}

It is simple to observe that some claims of attorney misconduct will be well founded, and others factitious. It is not so simple for the legal system to identify which are which. Great deference should be accorded the decision of the district judge, whose experience in conducting litigation and familiarity with the particular case generally enable him to decide the merits of a disqualification motion fairly. Some mechanism must be available, however, to review a blatantly incorrect order where special circumstances make the consequences to the party unusually harsh.

Since the district judge's ruling may ultimately be reviewed by the appellate court, it is tempting to permit the aggrieved party to take an appeal immediately, so that the question of the attorney's privilege to conduct.the litigation can be finally determined at the outset. It is certainly unsettling, and perhaps prejudicial to the parties, to leave such ethical challenges lingering in doubt. Nevertheless, it does not follow that immediate appeals of right are the appropriate way to review disqualification orders. The right to immediate appeal is a potent weapon for delay, and thus has adverse consequences for judicial administration as well as for the opposing party. The weapon is less disruptive, however, where disqualification has been granted than where disqualification has been denied. In the former situation, the lawsuit is already delayed while replacement counsel prepares himself. The granting of the disqualification motion, moreover, is persuasive evidence that there is some substantial reason for the challenge. Where the order in question denies disqualification, however, an appeal might significantly delay the trial and might be taken on wholly spurious grounds. Since appearances of conflict of interest are common, it is a relatively easy matter to delay by a factitious, but plausible, argument for reversal.

Although the Second Circuit in Silver Chrysler was motivated partly by the interests of judicial economy in deciding to grant appeal of right to denials of motions for disqualification, ${ }^{73}$ in practice such appeals are judicially uneconomical. This is not surprising since the Cohen exception, in general, satisfies the public and pri-

${ }^{73}$ "Since the ultimate objective is to bring before an appellate court an important question, which, if unresolved, might well taint a trial, why should not this question be presented before judicial and attorney time may have been needlessly expended?" Silver Chrysler Plymouth, Inc. v. Chrysler Motors, Inc., 496 F.2d 800, 806 (2d Cir. 1974). 
vate interest in speedy rectification at the expense of judicial economy.$^{74}$ Of course, when a final judgment is overturned and a new trial ordered because the trial court failed to disqualify an attorney, hindsight will say that less court time would have been wasted had an interlocutory appeal been taken. This is true, however, of any erroneous interlocutory order that would be grounds for reversal. The savings effected by interlocutory appeals in these rare cases are greatly outweighed by the costs of permitting such appeals in the more numerous cases where the issue is rightly decided or becomes moot, settled, or inconsequential before final judgment.

Autowest, Inc. $v$. Peugeot, Inc. ${ }^{75}$ illustrates that appellate courts can often make more discriminating judgments on interlocutory issues if appeal is delayed until final judgment. Plaintiff was represented at trial by its secretary and general counsel, who had participated in the transactions at issue. Defendant moved to disqualify him on the ground that he "would be" a witness in the trial..$^{78}$ The district judge denied the motion for disqualification and the case proceeded to final judgment. Had defendant won, there would have been no appellate consideration of the disqualification issue. But defendant lost and appealed, assigning the disqualification ruling as one of several points of error. Though noting that the attorney's "integrity, credibility, and professional status were intertwined inseparably with the issues of the case," "n and that "doubts should be resolved in favor of the lawyer testifying and against his becoming or continuing as an advocate,"78 the Second Circuit nevertheless affirmed the judgment. Examination of the trial record showed that the attorney had not testified and that he had "scrupulously" avoided use of personal recollection in his summation to the jury. The court concluded that the district judge, in

"See Borden Co. v. Sylk, 410 F.2d 843 (3d Cir. 1969):

Every interlocutory order involves, to some degree, a potential loss. That risk, however, must be balanced against the need for efficient federal judicial administration as evidenced by the Congressional prohibition of piecemeal appellate litigation. To accept the appellant's view is to invite the inundation of appellate dockets with what have heretofore been regarded as nonappealable matters. It would constitute the courts of appeals as second-stage motion courts reviewing pretrial applications of all non-party witnesses alleging some damage because of the litigation.

Id. at 846 .

${ }^{73} 434$ F.2d 556 (2d Cir. 1970).

7 Disciplinary Rule DR 5-101 (B) of the Code of Professional Responsibility provides that "A lawyer shall not accept employment in contemplated or pending litigation if he knows or it is obvious that he or a lawyer in his firm ought to be called as a witness . . . " ABA CODE of Profzssional ResponsibILITY 27 (1975).

37434 F.2d at 568.

7s Id. at 569 (quoting Ethical Consideration 5-10 of the Code of Professional Responsibility). 
denying the motion, "did not abuse his discretion, and that subsequent occurrences at trial do not warrant reversal on this ground."79 Had there been an interlocutory appeal, not only would the case have been delayed and the courts burdened, but a costly and timeconsuming disqualification might have been ordered when hindsight showed that the remedy was unnecessary for a fair trial.

These considerations-the strain on appellate court dockets by expansion of piecemeal review, the cessation of district court proceedings pending appeal, and the unrestricted opportunity which interlocutory appeal affords parties for further costly harassment of adversaries-counsel strongly against permitting appeal of right from motions denying attorney disqualification. Unlike appeals from orders granting disqualification, appeals from orders denying disqualification afford virtually unlimited possibilities for abuse. Disqualification denials should not be appealable as of right, not only because they fail to meet the Cohen criteria, but also because they are undesirable in practice.

\section{Limited Appeal of Right}

Dissatisfied with the practical results of its Silver Chrysler rule, the Second Circuit has taken steps to cut back on the volume of appellate litigation over attorney disqualification. In Lefrak v. Arabian American Oil Co. ${ }^{80}$ the court refused to reverse the lower court's decision not to disqualify, emphasizing that certain violations of the Code of Professional Responsibility are not grounds for disqualification in the absence of such injury to the moving party as would "taint" the trial. ${ }^{81}$ Though the parties had not raised the issue, the court speculated that an order denying disqualification might not be appealable at all in the absence of such injury and taint. The rationale of Silver Chrysler, the court stated, applies only where there is such taint as would lead to "a waste of attorney and judicial trial time." 82 The court repeated this characterization of Silver Chrysler the following year in W.T. Grant Co. v. Haines. ${ }^{83}$

\footnotetext{
79 Id. at 567 .

so 527 F.2d 1136 (2d Cir. 1975).

st Id. at 1139-40.

82 Id. at 1139 .

$\$ 531$ F.2d 671 (2d Cir. 1976) (attorney accused of violating Canon 7 by communicating directly with an opposing party):

While disqualification is clearly punitive insofar as [appellee] and its outside counsel are concerned, its benefit to [appellant] is indeed questionable. The business of the court is to dispose of litigation and not to act as a general overseer of the ethics of those who practice here unless the questioned behavior taints the trial of the cause before it. . . . If [challenged counsel] is guilty of professional misconduct . . . the appropriate
} 
The Second Circuit's reinterpretation of Silver Chrysler has so far affected only the standard of review, but the court's logic suggests a new approach to appealability as well. Under this possible new approach, appeal of right would lie only when an appellant could prove "taint"- that the order below would seriously impair his right to a fair trial. Appealability would thus be judged on a case-by-case basis: ${ }^{84}$ when no "taint" is shown, appeal would not lie, no matter how erroneous the order below. This approach would be similar to that which the Second Circuit has taken to the appealability of orders granting consolidation of stockholders' actions. At present, direct appeals from such orders are allowed only if the order consolidates the action in such a way as effectively to deny a party his due process right to prosecute his separate claim. ${ }^{85}$ The appealability determination involves a somewhat detailed examination of the claims in the main case and the scope of the order. In a disqualification case, the appellate court, under a "taint" doctrine, would examine the claim to determine whether counsel's unethical behavior prejudices the appellant's claim. The court would therefore have to examine in some detail an appellant's proof of prospective injury. ${ }^{86}$

There are several drawbacks to such an approach. ${ }^{87}$ First, it is doctrinally questionable, sharing most of the defects of the full Silver Chrysler rule. The Cohen requisites of public importance and impracticability of review from final judgment are lacking. ${ }^{88}$ The artful movant, moreover, will continue to be able to force unwar-

forum is the Grievance Committee of the bar association.

Id. at 677 .

st This seems to have been the original position of the Third Circuit. In Greene v. Singer

Co., 509 F.2d 750 (3d Cir. 1971), cert. denied, 409 U.S. 848 (1972), the court said:

We do not hold that every ruling relating to conflict of interest by an attorney should activate the Cohen rule. We decide only that these facts present compelling argument that the "rights asserted in the action [are] too important to be denied review and too independent of the cause itself" to require a postponement of appellate consideration. Id. at 751 (footnote omitted).

ss Garber v. Randell, 477 F.2d 711 (2d Cir. 1973).

s6 Cf. Kohn v. Royall, Koegel \& Wells, 496 F.2d 1094 (2d Cir. 1974) (appeal of order certifying class in a class action suit, under the doctrine in Herbst v. ITT Corp., 495 F.2d 1308 (2d Cir. 1974), dismissed after lengthy discussion of the minimal injury to defendant from the order).

"Indeed, Judge Friendly has recommended abandonment of the Garber approach; he would deny all appeals of consolidation orders. In his view, halfway measures such as Garber cannot correct the original mistake of granting appeals. Katz v. Realty Equities Corp., 521 F.2d 1354, 1363-64 (2d Cir. 1975) (Friendly, J., concurring).

s By limiting appeals to cases involving serious injury to the movant, the courts could move closer to satisfying the impracticability of final appellate review requisite. However, the remaining cases would still lack the element of impossibility of rectification evident in Cohen and its progeny. 
ranted expenditure of judicial and opponent resources. The focus of argument will simply shift from the substantive issue, under Silver Chrysler, to the threshold question of "taint." Though the latter inquiry is of lesser scope, it is unlikely that the hoped-for savings of court and party time would be of much magnitude. Furthermore, the flexibility of the rule would encourage litigation. As the District of Columbia Circuit noted in another context, "exemptions to the final judgment rule . . . should be indulged only in clearly and narrowly defined areas to maintain the wholesome deterrence of the final judgment rule." ${ }^{89}$ Only a clean and categorical rule can avoid the dangers of a lengthy and uncertain analysis of the appealability question..$^{90}$ The excesses of the Silver Chrysler rule would be better corrected by replacing it with a clear judgment against immediate appealability by right.91

\section{Discretionary Modes of Review: Section 1292(B) and MaNdaMus}

The problem with recognizing a class of interlocutory orders as appealable under section 1291 is that all appeals of orders of that class then come within the mandatory jurisdiction of the courts of appeals. Litigants are thus given the opportunity to protract the proceedings, burdening the judicial system and imposing costs and delays on the opposing parties. The potential for abusing the right to immediate appeal of orders denying disqualification is so great that appealability of right should be rejected. Discretionary modes of review, on the other hand, enable courts to pick and choose particularly worthy cases from among the general class, and thus are not nearly as susceptible to abuse. Possible discretionary modes of review from orders denying disqualification are (1) interlocutory appeal under section $1292(\mathrm{~b})$, and (2) the writ of mandamus.

\section{A. Interlocutory Appeal under Section 1292(b)}

In 1958 Congress attempted to mitigate some of the inefficiencies and hardships of the final judgment rule by enacting the Interlocutory Appeals Act, ${ }^{92}$ now section 1292(b) of the Judicial Code.

${ }^{89}$ Colonial Times, Inc. v. Gasch, 509 F.2d 517, 523 (D.C. Cir. 1975) (footnote omitted).

${ }^{90}$ Compare Hull v. Celanese Corp., 513 F.2d 568 (2d Cir. 1975), and Marco v. Dulles, 268 F.2d 192 (2d Cir. 1959), with Kohn v. Royall, Koegel \& Wells, 496 F.2d 1094 (2d Cir. 1974), and Garber v. Randell, 477 F.2d 711 (2d Cir. 1973).

"This is the conclusion reached in Community Broadcasting of Boston, Inc. v. FCC, 546 F.2d 1022 (D.C. Cir. 1976), and hinted at in Allegaert v. Perot, 565 F.2d 246 (2d Cir. 1977).

${ }^{2}$ Pub. L. No. 85-919, 72 Stat. 1770 (1958) (codified at 28 U.S.C. § 1292(b) (1970)). 
The Act provides for interlocutory appeal of a carefully limited class of orders. If, on timely motion, the district judge finds that (1) the order involves a controlling question of law; (2) there is substantial ground for difference of opinion as to that question; and (3) immediate appeal might materially advance the ultimate termination of the litigation, section 1292(b) directs that he "so state in writing in such order." ${ }^{33}$ The court of appeals then has unfettered discretion to either grant or refuse to grant an appeal..$^{94}$

This certification procedure has not been widely used for appeal of attorney disqualification orders, partly because most circuits currently entertain appeals of right from orders granting or denying disqualification..$^{95}$ Judicial opinion varies in the scant caselaw on certification of attorney disqualification rulings. The District of Columbia Circuit has endorsed the use of section 1292(b), ${ }^{98}$ but the Ninth Circuit, reversing an earlier endorsement, ${ }^{97}$ has recently held that certification is an "improper avenue" for obtaining review of denials of disqualification..$^{88}$ The Tenth Circuit in one case entertained an application for appeal from a disqualification denial but exercised its discretion not to hear the certified question.99

It is necessary to examine judicial interpretation of section 1292(b) in order to determine whether certification can substitute for section 1291 appeal of orders denying disqualification. The statutory requirement that the order involve a "controlling question of law" presents the most problems. A question is considered to be "controlling" if it is "serious" to the conduct of the litigation ${ }^{100}$ and

is 28 U.S.C. \& 1292(b) (1970).

of The statute provides:

When a district judge, in making in a civil action an order not otherwise appealable under this section, shall be of the opinion that such order involves a controlling question of law as to which there is substantial ground for difference of opinion and that an immediate appeal from the order may materially advance the ultimate termination of the litigation, he shall so state in writing in such order. The Court of Appeals may thereupon, in its discretion, permit an appeal to be taken from such order, if application is made to it within ten days after entry of the order: Provided, however, that application for an appeal hereunder shall not stay proceedings in the district court unless the Id. district judge or the Court of Appeals or a judge thereof shall so order.

"s An order may be certified only if it is "not otherwise appealable."

* Community Broadcasting of Boston, Inc. v. FCC, 546 F.2d 1022, 1028 \& n.40 (D.C. Cir. 1976).

${ }^{7}$ Cord v. Smith, 338 F.2d 516, 521-22 (9th Cir. 1964), clarified, 370 F.2d 418 (9th Cir. 1966).

8 Trone v. Smith, 553 F.2d 1207 (9th Cir. 1977).

n Waters v. Western Co. of N. Am., 436 F.2d 1072 (10th Cir. 1971) (dismissing appeal as improvidently granted).

${ }^{100}$ Katz v. Carte Blanche Corp., 496 F.2d 747, 755 (3d Cir.), cert. denied, 419 U.S. 885 (1974). 
if an erroneous ruling on the matter would constitute reversible error on final appeal. ${ }^{101}$ Although some courts have interpreted the concept more restrictively, as meaning that a question is controlling "only if it may contribute to the determination, at an early stage, of a wide spectrum of cases," 102 this position is not supported by the language of the statute or the legislative history. The Act makes no reference to the effect of an appeal on other cases, and the Senate Report on the legislation makes clear that the certification procedure was designed to facilitate the course of the particular litigation, rather than to supervise district courts or to set precedent. ${ }^{103}$ Since denials of disqualification are grounds for reversal if erroneous and are clearly serious to the conduct of the case, the questions presented by disqualification motions are "controlling" questions.

More difficult is the question whether an issue of possible abuse of discretion can amount to a "controlling question of law." Many courts have held that section 1292(b) appeals cannot be maintained "to test the propriety of a district judge's exercise of discretion."104 This position is consistent with the statutory language. When the trial judge has wide discretion in applying general legal standards to complicated factual situations, questions of fact and characterization of the facts, not questions of law, will largely predominate. Moreover, the position, if not carried to restrictive extremes, accords with the legislative purpose. When abuse of discretion is the standard of review, chances of reversal on appeal will be slight, and interlocutory appeal will be likely to yield unproductive delay rather than the expeditious conclusion that is supposed to result from 1292(b) appeal. The Second Circuit captured the crucial distinction in A. Olnick \& Sons v. Dempster Brothers, Inc. ${ }^{105}$ It ruled that the

101 See generally Note, Discretionary Appeals of District Court Interlocutory Orders: A Guided Tour through Section 1292(b) of the Judicial Code, 69 YALE L.J. 333, 342 (1959).

102 Kohn v. Royall, Koegel \& Wells, 59 F.R.D. 515, 525 (S.D.N.Y. 1973) (summarizing Second Circuit precedent), appeal dismissed, 496 F.2d 1094 (2d Cir. 1974). The Kohn position does not accurately reflect Second Circuit practice. The Circuit's actual position is better stated in A. Olnick \& Sons v. Dempster Bros., Inc., 365 F.2d 439 (2d Cir. 1966), discussed in text at notes 105-106 infra.

${ }^{103}$ S. REP. No. 2434, 85th Cong. 2d Sess. 8-10 (1958).

104 Katz v. Carte Blanche Corp., 496 F.2d 747, 765 (3d Cir.) (dissenting opinion), cert. denied, 419 U.S. 885 (1974). See also Garner v. Wolfinbarger, 433 F.2d 117; 119-20 (5th Cir. 1970); United States v. Salter, 421 F.2d 1393 (1st Cir. 1970); A. Olnick \& Sons v. Dempster Bros., Inc., 365 F.2d 439, 443 (2d Cir. 1966); Phelps v. Burnham, 327 F.2d 812, 814 (2d Cir. 1964); Atlantic City Elec. Co. v. A.B. Chance Co., 313 F.2d 431, 434 (2d Cir. 1963) (per curiam); 9 Moore's, supra note 7, I 110.22[2], at 261; C. WRIGHT, HaNDBOOK OF THE LAW OF Federal Courts $\$ 102$, at 518 (3d ed. 1976). But see Katz v. Carte Blanche Corp., 496 F.2d 747, 752-56 (3d Cir. 1975), cert. denied, 419 U.S. 885 (1974); Note, Interlocutory Appeals in the Federal Courts under 28 U.S.C. $\$ 1292(b), 88$ HARv. L. REv. 607, 618 n.57 (1975).

${ }^{105} 365$ F.2d 439 (2d Cir. 1966). 
"controlling question of law" requirement might be met where there is some question whether the district court considered the proper factors in reaching its conclusions, but not where the correct factors were considered, with the wrong result. ${ }^{108}$ Under this approach, denials of motions for counsel disqualification would present controlling questions of law only when the applicable ethical standards are uncertain.

The second statutory criterion-that there be a substantial ground for difference of opinion-has been little discussed and seems to function only as a block to frivolous appeals. Unless he is uncertain of the correctness of his ruling, a district judge will have little reason to certify an order. ${ }^{107}$ It is therefore likely that this condition will be satisfied whenever the other conditions are met.

The final requirement for section $1292(\mathrm{~b})$ certification, which has been called the "most basic,"108 is that immediate appeal be likely to advance materially the ultimate termination of the litigation. This entails comparing the likely course of the litigation if appeal is not immediately taken, on the one hand, with its probable course if appeal is taken, on the other. In the attorney disqualification context, the immediate consequence of interlocutory appeal when the disqualification decision has been made on improper factors will be a delay, both during the appellate procedure and, assuming reversal, during the time needed for the district judge to consider the motion under the proper standards. If the order is not appealed immediately, however, reversal on appeal from final judgment might lead to duplication of the entire proceeding, thus postponing "ultimate termination" even longer. Thus, the material advancement requirement presents no special obstacle to certification of attorney disqualification questions. ${ }^{109}$

Application of the statutory criteria leads to the conclusion that a small number of orders denying attorney disqualification, those resting on standards of uncertain applicability, can be reviewed by

100 Id. at $442-43$.

${ }^{107}$ Katz v. Carte Blanche Corp., 496 F.2d 747, 754-55 (3d Cir.), cert. denied, 419 U.S. 885 (1974).

${ }^{10 s}$ Note, Discretionary Appeals of District Court Interlocutory Orders: A Guided Tour through Section 1292(b) of the Judicial Code, 69 YALE L.J. 333, 343 (1959).

tof Whether termination of the litigation would be advanced by interlocutory appeal depends in large part upon the stage of the litigation at which the motion for disqualification was made and denied. Early in the process, before discovery and most pretrial maneuvering, direct appeal, if resulting in reversal, would avoid duplicating lengthy litigation. Near the close of the litigation little time would be saved. Termination of litigation is advanced only in cases where the district court is reversed, but the certification procedure should ensure that only cases with a substantial likelihood of reversal are appealed. 
way of section $1292(\mathrm{~b})$ certification. As a practical matter, Cohen appeals frequently produce a similar result, for the appellate court often will simply state the applicable legal rules and remand for the district court to apply them. ${ }^{110}$ The distinction between $1292(\mathrm{~b})$ appeals and appeals of right is that 1292(b) appeals will be taken only when district and appellate judges believe the appeal will materially advance the litigation. Also, the application for a section 1292(b) appeal does not perforce stay the district court proceedings. ${ }^{11}$ The appellant is not afforded the opportunity to harass his opponent and delay the trial on trumped-up appeals. Because of these safeguards, 1292(b) appeal is superior to immediate appeal of right, at least in the class of cases where it is available. ${ }^{112}$

\section{B. Mandamus}

The writ of mandamus is the least restricted mode of appellate review. The statutory authority for its exercise, the All Writs Act, broadly grants to the Supreme Court and other federal courts the power to issue "all writs necessary or appropriate in aid of their respective jurisdictions and agreeable to the usages and principles of law."113 Review of interlocutory orders by way of mandamus differs in several important respects from section 1291 review under Cohen. An appellate court has discretion to reject petitions for mandamus without a hearing and upon submissions from the petitioner only. ${ }^{114}$ Concededly, section 1291 appeals may be summarily dismissed, but courts appear to give them more serious attention than mandamus petitions because of the statutory obligation to hear appeals. ${ }^{115}$ Perhaps even more important is that appellate courts receive information with which to evaluate mandamus petitions. The petitioner must specify the ground claimed to justify issuance of the writ, together with a summary of the case and such parts of

"10 See, e.g., Wilson P. Abraham Constr. Corp. v. Armco Steel Corp., 559 F.2d 250 (5th Cir. 1977).

i11 28 U.S.C. \$ 1292(b) (1970).

112 This conclusion holds true even under the liberalized approach taken by the majority in Katz v. Carte Blanche Corp., 496 F.2d 747, 752-56 (3d Cir.), cert. denied, 419 U.S. 885 (1975), which would permit $\$ 1292$ (b) appeals of orders involving trial judge discretion. The safeguards of $\$ 1292(\mathrm{~b})$ would still impede dilatory appeals of right. See Ackerly v. Red Barn Sys., Inc., 551 F.2d 539 (3d Cir. 1977): "[T]his Circuit has consistently maintained that the collateral order doctrine should be sparingly applied, and that utilization of section $1292(\mathrm{~b})$ rather than relaxation of standards for mandatory appeals should be seen as the preferred vehicle for seeking review of arguably interlocutory orders." Id. at 543 (footnote omitted).

11328 U.S.C. $\$ 1651$ (a) (1970).

11 Fed. R. App. P. 21(a), (b).

"Ss See, e.g., 9 Moore's, supra note 7, I 110.10, at 136. 
the record as he may consider important. ${ }^{116}$ And because mandamus petitions are given priority over other matters on the appellate docket, ${ }^{117}$ courts can dispose of meritless petitions without delay. In contrast, a notice of appeal contains no such information about the case. ${ }^{118}$ The appellant has ten days within which to order the trial court record, which is to be delivered to the appellate court within forty days. ${ }^{110}$ The appeal is then docketed ${ }^{120}$ and a briefing schedule established; appellant's brief is generally due within forty days of the filing of the record, appellee's brief thirty days after that, and the appellant's reply brief within fourteen days of that. ${ }^{121}$ Only then does the appellate court have the information needed to assess the worthiness of the appeal. Thus even summary dismissal of an appeal takes far longer than denial of mandamus.

Because incontinent use of mandamus would subvert the final judgment principle and disrupt ordinary appellate procedures, courts traditionally have limited its usage to exceptional situations. ${ }^{122}$ Unfortunately, the resultant body of doctrine is replete with conflicting formulations and confusing terminology, making it difficult to determine the propriety of mandamus in types of situations not squarely addressed by existing precedent. That mandamus is characterized by strict theory and loose practice further complicates the problem. ${ }^{123}$ Examination of the principal Supreme Court cases, however, yields certain doctrinal principles with which to evaluate the appropriateness of using the writ to review disqualification denials.

1. Mandamus in the Supreme Court. Until the 1950s, the Supreme Court took a highly restrictive view of the scope of proper

\footnotetext{
116 FED. R. ApP. P. 21(a). This requirement may also have the psychological effect of discouraging groundless petitions. See, e.g., 9 Moone's, supra note 7, ๆ 110.10, at 136.

117 FED. R. APP. P. 23(b).

"18 FED. R. APP. P. 3(c) requires only that "the notice of appeal shall specify the party or parties taking the appeal; shall designate the judgment, order, or part thereof appealed from; and shall name the court to which appeal is taken."

1' FED. R. APP. P. 11(a).

120 FEd. R. APP. P. 12(a).

121 FED. R. APP. P. 31(a).

12 C. Wright, The Handbook of the Law of the Federal. Courts $\$ 102$, at 516 (3d ed. 1976)

${ }_{123}$ Since the standards for use of mandamus are difficult to define precisely, courts and parties are able to characterize erroneous orders of varying degrees of seriousness as "abuse of discretion" or "usurpation of authority." Thus, courts hear cases not strictly appropriate to mandamus even while enunciating strict standards. See, e.g., In re Evans, 524 F.2d 1004, 1007 (5th Cir. 1975). That this is the prevailing practice is best shown by the prevalence of judicial statements of concern about keeping the writ within proper limits. See, e.g., Bauman v. United States Dist. Court, 557 F.2d 650, 653-54 (4th Cir. 1977); A. Olnick \& Sons v. Dempster Bros., Inc., 365 F.2d 439, 445-48 (2d Cir. 1966) (Friendly, J., concurring).
} 
appellate use of mandamus to correct district court errors. ${ }^{124}$ Even so, the standards were ambiguous and thus open to manipulation by courts and attorneys. It was said that mandamus was a way of obliging courts "to do that justice which they are in duty, and by virtue of their office, bound to do," 125 and that "[i]t does not lie to control judicial discretion," except to remedy trial court abuses "outside of the exercise of [judicial] discretion, and outside the jurisdiction of the court . . . ." ${ }^{126}$ Even in such cases, doctrine held that appellate courts should reserve the remedy for "extraordinary causes," and should not interfere with decisions of a lower court on jurisdictional questions that the lower court is competent to decide and that are reviewable in the regular course of appeal. ${ }^{127}$ Mandamus was said not to be available "to perform the office of an appeal-even if no appeal is given by law."128

In 1957 in La Buy v. Howes Leather Co. ${ }^{129}$ the Court expanded the scope of mandamus when it approved the Seventh Circuit's issuance of the writ to correct a district judge's erroneous referral of a case to a special master. Rule 53 grants the district courts discretion to make such referrals in "exceptional" cases. ${ }^{130}$ Thus, it was arguable that the lower court had merely erred in its discretionary determination that exceptional circumstances existed and that the case was therefore an inappropriate one for use of mandamus. The Supreme Court nevertheless found that use of mandamus had been justified because "supervisory control of the District. Courts by the Courts of Appeals is necessary to proper judicial administration." 131 In support, the Court gave an expansive reading to the 1927 case Los Angeles Brush Corp. $v$. James, ${ }^{132}$ quoting it to say that " "[w]here the subject concerns the enforcement of the ... [r]ules which by law it is the duty of this Court to formulate and put into force,' mandamus should issue to prevent such action thereunder so palpably improper as to place it beyond the scope of the rule invoked."133

${ }^{224}$ See Note, Supervisory and Advisory Mandamus under the All Writs Act, 86 HaRv. L. REv. 595, 598-602 (1973).

125 Virginia v. Rives, 100 U.S. 313, 323 (1879). See also Roche v. Evaporated Milk Ass'n, 319 U.S. 21, 26 (1943).

126 Virginia v. Rives, 100 U.S. 313,323 (1879).

${ }_{12 \pi}$ Ex parte Fahey, 332 U.S. 258, 260 (1947); In re Rice, 155 U.S. 396, 403 (1894) ("Mandamus cannot be issued to compel a lower court to decide a matter before it in a particular way, or to review its judicial action had in the exercise of legitimate jurisdiction").

${ }^{128}$ In re Rice, 155 U.S. 396, 403 (1894).

129 352 U.S. 249 (1957).

130 FED. R. Crv. P. 53 ("reference to a master shall be an exception").

เ31 352 U.S. at 259-60.

132272 U.S. 701 (1927).

133352 U.S. at 256 (quoting Los Angeles Brush Corp. v. James, 272 U.S. 701 (1927)). 
The Court emphasized that references to special masters were "all too common in the Northern District of Illinois," 134 suggesting perhaps that the case only approves mandamus where a district judge makes the same error repeatedly. But the Court seemed to imply that proof of repeated errors is unnecessary, by saying "[b]ut even 'a little cloud may bring a flood's downpour' if 'we approve the practice here indulged . . . ." ${ }^{135}$ One appellate court has remarked that mandamus would be proper in "[e]xtraordinary circumstances . . . where the order under attack is characteristic of an erroneous practice likely to reoccur." ${ }^{136}$ Indeed, La Buy might be broadly read to support mandamus where a district court's order or practice, although an exercise of its discretion, is so palpably improper as to move the appellate court to exercise its supervisory authority. ${ }^{137}$

The Court's decision in Schlagenhauf $v$. Holder ${ }^{138}$ further broadened the scope of the writ. In that case the district court was alleged to have overreached its powers by ordering a defendant to undergo a series of physical and mental examinations pursuant to rule 35 of the Federal Rules of Civil Procedure. Although reversing the appellate court's view of the merits of the order, the Supreme Court sanctioned its use of mandamus as a method of resolving an important legal issue of first impression. This practice has become known as "advisory" mandamus.

Whether these supervisory and advisory uses of mandamus survive the later case of Will $v$. United States ${ }^{139}$ is a matter of dispute among the commentators. ${ }^{140}$ Will disapproved the use of mandamus

${ }^{334} 352$ U.S. at 258 (quoting Krinsley v. United Artists Corp., 235 F.2d 253, 257 (7th Cir. 1956)).

135352 U.S. at 258. Admittedly, the Court referred to past Seventh Circuit opinions criticizing the practice of referrals to special masters and noted that Judge La Buy had referred eleven cases in six years. Id. But, as observed in Note, Supervisory and Advisory Mandamus under the All Writs Act, 86 HaRv. L. Rev. 595, 609 (1973), the Court did not say what proportion of possible referral cases were referred, or whether the number of cases referred was unusually high. Significantly, the decision below, 226 F.2d 703 (7th Cir. 1955), makes no mention of the district court's repetition of the error. The dissent implies that Judge La Buy's referral was not "a wholesale reference," nor "in accordance with or by reason of a plan, practice, or custom." Id. at 713.

${ }^{136}$ General Motors Corp. v. Lord, 488 F.2d 1096, 1099 (8th Cir. 1973). See also United States v. United States Dist. Court, 444 F.2d 651, 655 (6th Cir. 1971), aff'd, 407 U.S. 297 (1972); Comment, The Use of Extraordinary Writs for Interlocutory Appeals, 44 TENN. L. REv. 137, 146-56 (1976); Note, Supervisory and Advisory Mandamus under the All Writs Act, 86 HARv. L. REv. 593, 608-12 (1973).

${ }^{137}$ See Wright, The Difficult Omniscience of Appellate Courts, 41 Mins. L. REv. 751, 77176 (1957) (calling the consequences of La Buy "truly breathtaking").

133379 U.S. 104 (1964).

เ39 389 U.S. 90 (1967).

${ }^{H}$ See, e.g., 9 Moore's, supra note 7, II 110.28, at 308-13; C. WRight, HandBook of 
to review a discovery order in a criminal case. The Court reiterated the strict standards of the traditional cases, perhaps in an effort to limit the effects of La Buy and Schlagenhauf. La Buy was described in a footnote as "simply inapposite where there is no showing of a persistent disregard of the federal rules." 141 Schlagenhauf was described in the same footnote as resting "squarely on the fact that there was real doubt whether the District Court had any power at all to order a defendant to submit to a physical examination." ${ }_{142}$ On the other hand, the Will Court seemed to approve the basic premises of those cases when it spoke of the "vital corrective and didactic function" of the writ which "lay at the core" of $L a B u y$ and Schlagenhauf. ${ }^{143}$ Moreover, in emphasizing the "added weight" of the final judgment rule in criminal cases, ${ }^{144}$ and in distinguishing $L a$ Buy and Schlagenhauf as civil cases, ${ }^{145}$ the Court suggested-but specifically did not hold ${ }^{146}$ - that there might be a more stringent standard for the invocation of mandamus in criminal cases. ${ }^{147}$ It would therefore be premature to conclude that Will signalled a wholesale retreat from the expansion represented by La Buy and Schlagenhauf. ${ }^{148}$

2. Mandamus to Review Orders Denying Motions to Disqualify Counsel. The principles governing mandamus that have been sanctioned by the Supreme Court might support use of the writ in certain exceptional circumstances to review orders denying disqualification. Schlagenhauf might be authority for using mandamus to review a disqualification denial which involves the rare unsettled

THE LAW of The Federal CourTs \$ 102, at 517 (3d ed 1976); Redish, The Pragmatic Approach to Appealability in the Federal Courts, 75 Colum. L. Rev. 89, 115 (1975).

in 389 U.S. at 104 n.14.

112 Id.

${ }^{143}$ Id. at 107.

iss Id. at 96.

165 Id. at 100 n.16.

196 Id.

187 But see Kerr v. United States Dist. Court, 426 U.S. 394, 402 (1976) which cites Will as precedent in a civil case, without comment on the possible distinction.

118 See C. Wright, Handbook of the Law of the Federal. Courts $\$ 102$, at 517 (3d ed. 1976). Two recent Supreme Court decisions regarding mandamus do not clarify the law. Kerr v. United States Dist. Court, 426 U.S. 394 (1976), affirmed the appellate court's refusal to grant the writ to correct a discovery order where an alternative remedy was available. The opinion repeated the standard doctrinal phrases, but the case required no further analysis. The Court intimated that the courts of appeals have latitude in granting or denying the writ, stating "it is important to remember that issuance of the writ is in large part a matter of discretion with the court to which the petition is addressed." Id. at 403 .

In Thermtron Prods., Inc. v. Hermansdorfer, 423 U.S. 336 (1976), the Court reversed the Sixth Circuit's decision not to issue mandamus to reverse the district court's remand of a removed case to state court. The Court relied on the traditional use of mandamus to compel a lower court to exercise its authority when it has the duty to do so. Id. at 352-53. 
question of law. ${ }^{149}$ In such cases, mandamus would provide an alternative means of review where $1292(\mathrm{~b})$ is appropriate and the district judge fails to certify. ${ }^{150}$ And although $L a B u y$ could be read to apply only when a district judge repeatedly makes the same error, ${ }^{151}$ the case can be read more broadly as sanctioning mandamus as a means of redressing gross abuses of judicial discretion. Thus, if a trial court refused to disqualify in a very clear case for doing so, or denied a disqualification motion in wholly cavalier fashion, mandamus might lie under the $L a$ Buy case. But if $L a B u y$ is limited to cases involving often-repeated error, or erroneous practices likely to be repeated, then erroneous denials of disqualification will not be remediable by supervisory mandamus unless the trial court's behavior is part of a persistent practice of disregarding the canons.

Beyond the fairly specific and limited situations in which either supervisory or advisory mandamus is available, the Supreme Court cases provide little guidance. If $L a B u y$ is given a restrictive interpretation, the litigant aggrieved by a grossly erroneous denial of disqualification might find succor in an early Supreme Court case which, surprisingly in light of mandamus theory prevailing at the time, suggested that mandamus will lie to correct flagrant trial court error or misconduct. In Ex parte Burr ${ }^{152}$ the Court denied a petition for a writ filed by an attorney who had been suspended from practice before an inferior court. Writing for the Court, Chief Justice Marshall stated that the Court was not inclined to intervene "unless it were in a case where the conduct of the Circuit or District Court was irregular, or was flagrantly improper."153 In Ex parte Secombe, ${ }^{154}$ on the other hand, Chief Justice Taney wrote on behalf of the Court that mandamus was not available to review an attorney's disbarment, no matter how erroneous the decision may have been. He commented that the Court was not aware of any case where mandamus had issued to a lower court "commanding it to reverse or annul its decision, where the decision was in its nature a judicial act, and within the scope of its jurisdiction and discretion." ${ }^{155}$ As rulings on disqualification motions are generally said to

19 See Note, Supervisory and Advisory Mandamus under the All Writs Act, 86 Harv. L. REv. 595, 613-19 (1973).

150 The circuits do not agree on whether a motion for certification under $\S 1292(\mathrm{~b})$ and denial of it by the district judge are prerequisites to petitioning for mandamus. See 9 Moore's, supra note 7, If 110.22[5], at 267.

เs1 See text and notes at notes 134-36 supra.

15222 U.S. (9 Wheat.) 529 (1824).

${ }^{133} \mathrm{Id}$. at 530 . Since suspension and disqualification are similar means of regulating the conduct of the Bar, the Court's analysis should apply to disqualifications as well.

is 60 U.S. (19 How.) 9 (1857).

iss Id. at 15. 
be within the discretion of the district court, this position seems to undercut the Burr dictum unless a petitioner could successfully argue that a particular denial of disqualification was so "flagrantly improper" as to be beyond the scope of the district court's discretion.

The caselaw in the courts of appeals reflects the lack of specific guidance from the Supreme Court. Some circuits have adopted strict formulations of the prerequisites for mandamus, ${ }^{156}$ while others employ more liberal formulations. ${ }^{157}$ An observer of appeals court practice might be inclined to agree with the dissenting judge in United States v. DiStefano ${ }^{158}$ that issuance of the writ depends in fact not upon ambiguous doctrinal statements in the Supreme Court cases, but upon "the importance the reviewing judges place upon the need for corrective action, and how serious they view the effect of their failure to act."159 A pragmatic approach to mandamus might be justified on the view that the opinion just quoted accurately describes the Supreme Court's decisions on mandamus as well. On this view, Schlagenhauf and La Buy (the Will opinion notwithstanding) are better viewed not as doctrinal pronouncements but as examples of a pragmatic approach in action.

In the recent case of Bauman v. United States District Court, ${ }^{160}$ the Ninth Circuit carefully articulated "guiding principles" for use of mandamus in an attempt to bring some needed clarity to the law. Five indicators favoring the use of mandamus were listed:

(1) The party seeking the writ has no other adequate means, such as a direct appeal, to attain the relief he or she desires .... (2) The petitioners will be damaged or prejudiced in a way not correctable on appeal. . . . (3) The district court's order is clearly erroneous as a matter of law. . . . (4) The district court's order is an oft-repeated error, or manifests a persistent disregard of the federal rules. . . . (5) The district court's order raises new and important problems, or issues of law of first impression. ${ }^{161}$

156 See, e.g., Donnelly v. Parker, 486 F.2d 402 (D.C. Cir. 1973); United States v. DiStefano, 464 F.2d 845, 849-50 (2d Cir. 1972).

157 See, e.g., Harper \& Row Publishers, Inc. v. Decker, 423 F.2d 487, 492 (7th Cir. 1970), aff'd per curiam by an equally divided court, 400 U.S. 348 (1971) (granting mandamus in a case of "substantial importance to the administration of justice" where ultimate appeal would be "an inadequate remedy").

${ }_{158} 464$ F.2d 845 (2d Cir. 1972).

${ }^{159}$ Id. at 853 (Lumbard, J., dissenting).

${ }^{160} 557$ F.2d 650 (9th Cir. 1977).

${ }^{181}$ Id. at 654-55 (citations omitted). 
Recognizing that "proper disposition will often require a balancing of conflicting indicators," the court termed the guiding principles "cumulative"-none of them being singly dispositive of the issue. ${ }^{162}$

A court of appeals applying these guidelines might issue the writ to correct a trial court's egregious error in denying a motion for disqualification. Where the Silver Chrysler rule is rejected and certification under 1292(b) denied, the first criterion would be met. The second criterion would be satisfied in the rare case in which special circumstances indicate that immediate disqualification is necessary adequately to protect the petitioner's interests. This determination is crucial, because the possibility of adequate relief upon appeal from final judgment eliminates the need for any mode of appellate review of the interlocutory order. Where the order is clearly wrong, the third criterion would be met. ${ }^{163}$ Presence of the fourth or fifth indicators, reflecting the "supervisory" and "advisory" uses of mandamus respectively, would strengthen the case for mandamus.

Use of mandamus in these sorts of attorney disqualification cases would not be out of line with current uses of mandamus to review other types of interlocutory orders. Mandamus is used to review, for example, discovery orders granting parties access to allegedly privileged documents; ${ }^{164}$ discovery orders requiring production of financial and tax records and attorney payment agreements; ${ }^{165}$ protective orders; ${ }^{166}$ orders denying the right to depose; ${ }^{167}$ orders convening a three-judge court; ${ }^{168}$ orders disqualifying judges $;^{169}$ orders granting retrial; $;{ }^{170}$ orders restraining parties and others from discussion of a pending case; ${ }^{171}$ and orders notifying

${ }^{102} I d$.

${ }^{163}$ See Grace Lines, Inc. v. Motley, 439 F.2d 1028 (2d Cir. 1971): "[M]andamus is required since it is the only way in which the appellate court can correct the egregious error of the district court . . . "Id. at 1034 (Lumbard, J., concurring).

16 Harper \& Row Publishers, Inc. v. Decker, 423 F.2d 487, 492 (7th Cir. 1970), aff'd per curiam by an equally divided court, 400 U.S. 348 (1971).

is Sanderson v. Winner, 507 F.2d 477, 479 (10th Cir. 1974), cert. denied, 421 U.S. 914 (1975).

${ }^{166}$ Rodgers v. United States Steel Corp., 536 F.2d 1001, 1006 (3d Cir. 1976).

167 Investment Properties Int'l, Ltd. v. IOS, Ltd., 459 F.2d 705 (2d Cir. 1972).

Is* Knight v. Alsop, 535 F.2d 466, 469 (8th Cir. 1976).

169 SCA Servs., Inc. v. Morgan, 557 F.2d 110, 117-18 (7th Cir. 1977); In re Rodgers, 537 F.2d 1196, 1197 n.1 (4th Cir. 1976); Pfizer, Inc. v. Lord, 456 F.2d 532, 536-37 (8th Cir. 1972), cert. denied, 406 U.S. 976 (1972); Rosen v. Sugarman, 357 F.2d 794, 796-97 (2d Cir. 1966). But see Action Realty Co. v. Will, 427 F.2d 843 (7th Cir. 1970); Albert v. United States Dist. Court, 283 F.2d 61 (6th Cir. 1960), cert. denied, 365 U.S. 828 (1961).

${ }^{70}$ In re United States, No. 77-1267 (1st Cir., Nov. 8, 1977); Peterman v. Chicago, R.I. \& P.R.R., 493 F.2d 88, 89 (8th Cir.), cert. denied, 417 U.S. 947 (1974); Grace Lines, Inc. v. Motley, 439 F.2d 1028 (2d Cir. 1971). But see General Motors Corp. v. Lord, 488 F.2d 1096, 1099-1100 (8th Cir. 1973); Thorn v. Parkland Chevrolet Co., 416 F.2d 95 (4th Cir. 1969).

${ }^{17 t}$ CBS, Inc. v. Young, 522 F.2d 234, 237 (6th Cir. 1975). 
potential class members of a pending class action. ${ }^{12}$ Although mandamus has been used in these situations, the practice does not extend indiscriminately to every instance of an order within the categories. Indeed, the courts generally decline mandamus review, reserving the writ for the special hardship case. ${ }^{173}$ This is consistent with the Supreme Court's admonition in Will v. United States ${ }^{174}$ that courts "be careful lest they suffer themselves to be misled by labels such as 'abuse of discretion' and 'want of power' into interlocutory review of nonappealable orders on the mere ground that they be erroneous." 175

Because vesting the appellate courts with mandatory jurisdiction of interlocutory appeals from orders denying disqualification increases the opportunity for abuse, parties aggrieved by such orders should be relegated instead to the remedy of mandamus, so that the appellate courts could decline to review all but those orders especially deserving of attention. Whatever the evils of expanded use of mandamus in general, use of the writ as a substitute for Cohen appeals in these cases is a move toward judicial economy. While the stricter traditional view of mandamus might make the writ unavailable in attorney disqualification cases, recent cases and the logic underlying them seem to support its use, at least in instances of egregious error. Indeed, both circuits that have rejected the majority view that these orders are appealable by right have endorsed the use of mandamus as an alternative. ${ }^{176}$ 1975).

12 Pan Am. World Airways, Inc. v. United States Dist. Court, 523 F.2d 1073 (9th Cir.

For additional instances of use of mandamus to review interlocutory orders see the cases collected in 9 Moore's, supra note 7, If 110.28, at 309-11.

173 The Sixth Circuit, for example, requires a showing of "the most extreme circumstances" to justify the writ. See Comment, The Use of Extraordinary Writs for Interlocutory Appeals, 44 TENN. L. REv. 137, 156 (1976). See generally Community Broadcasting of Boston, Inc. v. FCC, 546 F.2d 1022, 1028 n.40 (D.C. Cir. 1976); 9 Moore's, supra note 7, II 110.28, at 308-13.

17489 U.S. 90 (1967).

${ }^{175} I d$. at 98 n.6.

${ }^{376}$ Community Broadcasting of Boston, Inc. v. FCC, 546 F.2d 1022 (D.C. Cir. 1976); Chugach Elec. Ass'n. v. United States Dist. Court, 370 F.2d 441 (9th Cir. 1966), cert. denied, 389 U.S. 820 (1967); Cord v. Smith, 338 F.2d 516 (9th Cir. 1964), clarified, 370 F.2d 418 (9th Cir. 1966). Cf. In re Evans, 524 F.2d 1004 (5th Cir. 1975) (the court articulated a strict standard for the grant of mandamus, but nevertheless issued the writ where the district judge improperly refused to allow a particular attorney to appear in the case pro hac vice). The parallel to appeals from orders denying motions for disqualification of counsel on ethical grounds seems clear.

No reported decision holding mandamus inappropriate has been found, except insofar as direct appealability under the Silver Chrysler rule necessarily entails rejection of mandamus. In United States v. Hankish, 462 F.2d 316, 318-19 (4th Cir. 1972), the court rejected a petition for mandamus to review a lower court's grant of a motion to disqualify. The court suggested, rightly, that an appeal would be the proper avenue of review. 


\section{ConcLusion}

Mandamus, the Cohen collateral order exception, and certification of interlocutory orders under section 1292(b) are various means of ameliorating the sometimes harsh effects of the final judgment rule. Unfortunately, these modes of review were fashioned without reference to one another. The occasions for their use overlap, criteria relevant to the availability of one are imported into tests for availability of another, and the priorities accorded their use seem misplaced. Appeal of right from interlocutory orders is the least appropriate mode of review, because it offers the greatest opportunity for harassment and delay. Discretionary appeals under section 1292(b) should be more common, used freely whenever immediate appellate guidance on a controlling question of law would expedite the conduct of trial litigation. Mandamus should also be preferred to appeal by right because it provides a means of controlling delaying tactics and enables appellate courts to review interlocutory orders on a selective basis; appellate attention would be necessary only if the district court erred egregiously. Peculiarly, however, the Supreme Court has been relatively hospitable to claims of appealability under Cohen, and relatively hostile to the use of mandamus. ${ }^{177}$ District judges certify questions under section 1292(b) so infrequently that the statute has had little effect. ${ }^{178}$

Current practice regarding review of orders denying motions for disqualification of counsel illustrates these skewed priorities. If standards for disqualification are at issue, the order should be certified under 1292(b). In special circumstances, a trial court's egregious error in failing to disqualify can be corrected by mandamus. If the order is merely erroneous, the petitioner should be required to await final judgment, as in the cases of so many other interlocutory orders. But the majority of the circuits hear section 1291 appeals under Cohen instead of selectively using certification and mandamus. That position should be rejected, regardless of the availability of alternative modes of interlocutory review. In the disqualification context, the cost to the judicial system of appeal by

177 Compare Abney v. United States, 431 U.S. 651 (1977), Gillespie v. United States Steel Corp., 379 U.S. 148 (1964), and Roberts v. United States Dist. Court, 339 U.S. 844 (1950), with Kerr v. United States Dist. Court, 426 U.S. 394 (1976); Will v. United States, 389 U.S. 90 (1967); and Roche v. Evaporated Milk Ass'n, 319 U.S. 21 (1943).

${ }^{177}$ For example, in fiscal year 1974, 16,436 appeals were taken by the circuits, while only about one hundred appeals are certified each year under section 1292(b), half of them taken by the courts of appeals. C. WraGHT, HaNDBOOK OF THE LAW OF THE FEDERAL CourTs $\S 102$, at 518-19 (3d ed. 1976). Nor are mandamus cases common. See Redish, The Pragmatic Approach to Appealability in the Federal Courts, 75 CoLum. L. REv. 89, 115 n.149 (1975). 
right outweighs its occasional benefit to an unjustly denied movant, who still retains his right to eventual relief upon final judgment. Justice is sometimes neither quick nor sweet. But an attempt to hasten it is doomed to fail when it creates an unrestricted opportunity for litigants to harass an adversary and delay a trial.

Michael W. McConnell 